Discussion Paper No. 12-052

To Raise or Not to Raise?

Impact Assessment of

Russia's Incremental Gas Price Reform

Christophe Heyndrickx, Victoria Alexeeva-Talebi, and Natalia Tourdyeva

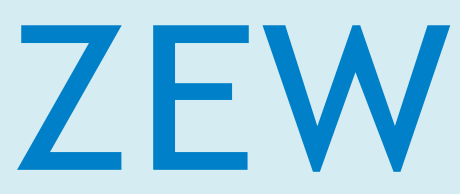

Zentrum für Europäische Wirtschaftsforschung $\mathrm{GmbH}$

Centre for European

Economic Research 


\title{
Discussion Paper No. 12-052 \\ To Raise or Not to Raise? Impact Assessment of Russia's Incremental Gas Price Reform
}

\author{
Christophe Heyndrickx, Victoria Alexeeva-Talebi, \\ and Natalia Tourdyeva
}

Download this ZEW Discussion Paper from our ftp server:

http://ftp.zew.de/pub/zew-docs/dp/dp12052.pdf

Die Discussion Papers dienen einer möglichst schnellen Verbreitung von neueren Forschungsarbeiten des ZEW. Die Beiträge liegen in alleiniger Verantwortung der Autoren und stellen nicht notwendigerweise die Meinung des ZEW dar.

Discussion Papers are intended to make results of ZEW research promptly available to other economists in order to encourage discussion and suggestions for revisions. The authors are solely responsible for the contents which do not necessarily represent the opinion of the ZEW. 


\section{Non-technical summary}

One of grand challenges which are faced by Russia today is to deregulate its gas market while favouring longer-term growth of economy. From the mid-2000s onwards, the key component of the reforms has become the introduction of a new pricing scheme for natural gas supply at the domestic markets. However, the growing momentum for gas price liberalization in Russia is currently constrained by fears of potentially strong adverse impact that market-based price setting principle will have on the economy. Based on a novel multi-regional, multi-sector and multi-household computable general equilibrium (CGE) model of the Russian Federation, this paper presents a simple yet a flexible framework for evaluating gas price reform. Specific model features include the regional disaggregation at the federal district level where each region has a special gas production and consumption structure, and the disaggregation of the household sector into income terciles. We found that the reform is feasible at low economic cost, without greater disparities in terms of increased inequity within and between country's federal districts. Large redistributive impacts can arise from specific mechanisms to recycle revenues. In terms of global environmental credentials, gas price liberalization can bring Russia on a substantially more sustainable path. The potential to foster adoption of energy efficiency measures by exploiting the revenue-recycling effect is, however, limited.

\section{Das Wichtigste in Kürze}

Russland steht derzeit vor einer seiner größten Herausforderungen, nämlich die Deregulierung des Gasmarktes mit einem langfristigen Wirtschaftswachstum zu verknüpfen. Zum Kernbestandteil von Reformen wird ab Mitte der 2000er Jahre die neue Preisregelung für die Erdgasversorgung auf dem heimischen Markt. Momentan wird aber die wachsende Dynamik im Preisliberalisierungsprozess durch die Befürchtung gehemmt, dass ein marktbasiertes Preissetzungsprinzip negative Folgen für die Volkswirtschaft haben kann. Mit Hilfe eines multiregionalen und multisektoralen berechenbaren allgemeinen Gleichgewichtsmodells Russlands untersucht dieses Papier die Implikationen der Gaspreisreformen. Spezifische Modelleigenschaften schließen die regionale Disaggregation auf Ebene der föderalen Bezirke mit einer eigenständigen Gasproduktions- und Konsumstruktur mit ein, sowie die Disaggreation der Haushalte in drei Einkommensterzile. Unsere Ergebnisse zeigen, dass die Gaspreisreformen in Russland zu geringen makroökonomischen Kosten machbar sind, ohne wachsende Disparitäten zwischen einzelnen föderalen Bezirken auszulösen. Negative Umverteilungseffekte können mit Hilfe unterschiedlicher Mechanismen zur Einnahmenverwertung (,revenue-recycling“) gemildert werden. Mit Hinblick auf die ökologischen Aspekte kann die Gaspreisliberalisierung Russland auf einen nachhaltigeren Pfad bringen. Das Potential, durch entsprechendes „revenue-recycling“ den stärkeren Einsatz von Energieeffizienzmaßnahmen zu fördern, ist aber begrenzt. 


\title{
To raise or not to raise?
}

\section{Impact assessment of Russia's incremental gas price reform}

Christophe Heyndrickx ${ }^{a}$, Victoria Alexeeva-Talebi ${ }^{b}$ and Natalia Tourdyeva ${ }^{c}$

\author{
${ }^{\mathrm{a}}$ Transport \& Mobility Leuven, Belgium \\ ${ }^{\mathrm{b}}$ Centre for European Economic Research (ZEW), Mannheim, Germany \\ ${ }^{\mathrm{c}}$ Centre for Economic and Financial Research (CEFIR), Moscow, Russia
}

Emails: christophe.heyndrickx@tmleuven.be, alexeeva-talebi@zew.de, ntourdyeva@cefir.ru

\begin{abstract}
:
The growing momentum for gas price liberalization in Russia is increasingly constrained by fears of potentially strong adverse impact that market-based price setting principle will have on the economy. Based on a novel multi-regional, multi-sector and multi-household computable general equilibrium (CGE) model of the Russian Federation, this paper presents a simple yet a flexible framework for evaluating gas price reform. We found that the reform is feasible at low economic cost, without greater disparities in terms of increased inequity within and between country's federal districts. Large redistributive impacts can arise from specific mechanisms to recycle revenues. In terms of global environmental credentials, gas price liberalization can bring Russia on a substantially more sustainable path. The potential to foster adoption of energy efficiency measures by exploiting the revenue-recycling effect is, however, limited.
\end{abstract}

JEL Classification: D58, H21, H22, Q48

Keywords: Regional general equilibrium model, sustainable development, natural gas pricing, Russia 


\section{Introduction}

One of grand challenges which are faced by Russia today is to deregulate its gas market while favouring longer-term growth of economy. Since the 1990s, several proposals for structural reforms of Russian gas industry have been intensively debated, including the split-up of Gazprom (Tsygankova, 2010). From the mid-2000s onwards, the key component of the reforms has become the introduction of a new pricing scheme for natural gas supply at the domestic markets. This is claimed to fit in a policy promoting energy efficiency, increasing investments in natural gas production and bringing the natural gas price on the domestic market closer to long term cost recovery.

Underpricing of natural gas at the domestic markets was an explicit feature of the Soviet era, aimed at stimulating industrial growth. In the post-Soviet period, domestic gas prices were kept at relatively low levels to back up economic recovery, though this strategy had become increasingly untenable by 2006 in the light of Gazprom's investment needs into new extraction fields. A number of studies supported an upward price correction as a prerequisite for any structural reforms of Russian gas industry (Locatelli, 2003; Stern, 2005). Price increases on domestic market have been considered as a remedy to overcome the risk of a shortage in Russian gas sector (Tsygankova, 2008). Since then domestic gas prices have been following a steady upward trend. The average regulated gas prices for both industrial consumers and private households have more than doubled from 2006 to $2011^{1}$. Nonetheless, today Russian consumers pay one third of the gas price charged abroad (Gazprom, 2011).

Notwithstanding the need for further price corrections on Russian gas market, a well-targeted strategy for price deregulation is needed to prevent severe hardship. The government is now seemingly engaged in trading-off the two objectives: On the one hand, it supports Gazprom's strategic drive to raise profits on domestic market in order to overcome the problem of chronic underinvestment in the gas industry. Roughly three quarters of infrastructure is estimated to be obsolete. New rounds of major price corrections have been already approved for 2012 and 2013 (Federal Tariff Service, 2011; Nezavisimaja Gaseta, 2012) ${ }^{2}$. On the other hand, Russian stakeholders are apparently not reluctant to an argument that further price increases would incur tremendous adjustment costs on domestic industry resulting in loss of comparative advantage and further narrowing of country's export mix. Likewise, private

\footnotetext{
${ }^{1}$ For the industrial sector prices increased from roughly US $\$ 44$ to US $\$ 97$; for private households from US\$33 to US\$75 (Gazprom 2011, Federal Tariff Service 2011, own calculations).

${ }^{2}$ Gazprom is reported to lobby currently the government for a $26 \%$ hike in the domestic gas tariff, on top of a $15 \%$ rise already granted for 2012 .
} 
consumers would face higher energy prices, rising unemployment and hence increasing social inequality. This explains why Gazprom's lobbying activities for the surge in prise in 2012 (beyond the scope of already approved price increases) and in particular its announcement to finance all the investment needs from domestic market sales have become a source of irritation even in the Russian government. The implementation of this plan would understandably make more radical price increases on domestic market necessary (Svobodnaja Pressa, 2012). In our paper we examine the conditions under which the Russian government can generate substantial investment inflows for Gazprom without sacrificing industrial competitiveness of energy-intensive sectors and rising severe distributional concerns.

In this paper, we present numerical simulations with a novel spatial computable general equilibrium (SCGE) model for Russia SUST-RUS. Our approach provides a comprehensive framework for studying the gas price reform in Russia as it addresses both economy-wide efficiency and distributional impacts of policy regulation. Specific model features include the regional disaggregation at the federal district level where each region has a special gas production and consumption structure, and the disaggregation of the household sector into income terciles. We compare the reference case, where Gazprom retains revenues generated through gas prices increases for infrastructure investments, and scenarios in which the additional revenues are partly compensated through lump-sum transfers to consumers or tax reductions involving labour taxes. In total, we consider 21 policy scenarios to estimate the impacts of price reform on Gazprom investment inflows, industrial competitiveness and consumer welfare at both federal and regional level. The paper also touches upon the effects of gas price increases on Russia's environmental sustainability.

The literature on Russian gas market in the context of European energy security is numerous (Kerkelä, 2004; Paltsev, 2011) but studies explicitly addressing domestic market effects of gas price increases are much less common. For example, Sagen and Tsygankova (2008) argued that rising Russian gas prices would influence the allocation of Russian gas supplied to Europe and Russia. The elimination of dual pricing - i.e. the equalization of the price of gas on European market and Russian market, once export taxes, transportation costs, and transit tariffs are adjusted for - would be necessary to avoid gas shortages in the future (Tsygankova, 2008). In contrast, Tarr and Thomson (2004) and Tarr (2010) argued that the price on the Russian domestic market should be increased to full cost recovery, but not higher to avoid social inequality. In the presence of environmental externalities, however, there is an economic rational to increase gas prices in Russia above the long run marginal costs of production. Holding gas prices at the lower edge implied that for decades there have been 
little incentives for both industrial consumers and private households to invest in any energy efficiency measures due to low financial returns (Bashmakov et al., 2008). Our study is probably the first to analyse all relevant trade-offs pertaining gas price increases on Russian market, including social and environmental implications.

We found that the envisaged reform will allow raising Gazprom's investment inflows to the levels required by independent analysis only when both households and firms will face doubling gas prices in comparison to the 2007 levels. But this is a regressive policy that calls for compensation by the government. In essence, the favourable recycling option boils down to a partial redistribution of revenues via lump-sum transfers. Labour tax cuts will favour the nonpoor most, given that unskilled labour in Russia already benefits from low tax rates. The increase of governmental spending that is characterized through a high level of inefficiency will put the middle class and the poor in the most unfavourable situation. Besides a pure revenue-generating motive, doubling gas prices will significantly improve country's energy efficiency. There is, however, a trade-off between decreasing global greenhouse gases such as $\mathrm{CO}_{2}$ and increasing local acidifying emissions such as $\mathrm{SO}_{2}$ due to a more extensive use of coal. In particular, in the Far East where main Russia's coal reserves are allocated, this effect will be rather substantial.

This paper has seven main sections: Section 2 describes the model used for the quantitative assessment. Section 3 highlights the data issues and empirical model parameterization. Section 4 defines policy scenarios. Section 5 presents discussion of the results. Section 6 summarizes main findings. Section 7 contains appendix with a more detailed discussion of data sources.

\section{The structure of the SUST-RUS model}

The SUST-RUS (Sustainable Russia) model is a novel multi-region, multi-sector and multihousehold dynamic recursive computable general equilibrium (CGE) model of the Russian Federation. For a detailed description and mathematical formulation see Heyndrickx at al. (2011). This model belongs to the group of spatial CGE (SCGE) models which apply a mix of conventional modelling techniques used in standard computable general equilibrium models at regional level. The SCGE approach builds on a concept introduced by the New Economic Geography School (Krugman, 1991; Fujita et al., 1999) and is used as a standard tool for impact assessment in many policy domains, including land and trade policy (e.g. Fan et al., 1998). In the version of the model used here, Russian Federation is divided in 7 federal 
districts: Central, North Western, South, Volga Basin, Ural, Siberian and Far Eastern. The sectorial aggregation covers 26 sectors in each federal district.

At each time period, the instantaneous behaviour of the sectors is based on the minimization of the production costs for a given output level under sector's technological constraints. Production possibilities are characterised through a three-level nested constant-elasticity-ofsubstitution (CES) production functions which allow for different degree of substitutability between production inputs. In each sector, output is produced from labour of three skill types (high skilled, medium skilled and low skilled), capital, fossil fuels and intermediate inputs. All production inputs in the CES function have a certain degree of substitutability. It is lowest on top of the nested CES function and highest at the bottom.

Final consumption is determined by regional representative households who maximise the utility level under the budget constraints. There are three types of households in each federal district: low, medium and high income households are determined according to their income per capita. Total income of representative households consists of net factor income, unemployment benefits and other transfers such as pensions from the federal government. It is assumed that the utility of households is separable in consumption and leisure. Consumption demand for commodities is captured by Stone-Geary utility or Least Expenditure function (Neary, 1997).

We do capture market imperfections in our modelling framework. Though there are few independent gas suppliers, Russian domestic gas market is arguably monopolistic. Gazprom is a direct owner of the transportation infrastructure and can easily deny access to pipelines or charge extra fee on other suppliers (Svobodnaja Pressa, 2012). Given this extreme dominant role, we assume the monopolistic competition of the Dixit-Stiglitz-type in the gas sector (see also Tarr and Thomson, 2004; Tsygankova, 2012).

Likewise, domestic labour market is characterised through market imperfections and equilibrium unemployment. We make use of a simplified wage curve in which household's participation in labour market depends on real market wage. Labour and capital are fully mobile across federal districts and sectors.

The model incorporates the representation of the federal and regional governments. The governmental sector collects taxes, pays subsidies and makes transfers to households, production sectors and the rest of the world. Each government gets two types of income: tax revenues from the economic agents within the region under its jurisdiction and income from inter-government transfers. The federal and regional governments consume a number of 
commodities and services, where the optimal governmental demand is determined according to the maximization of the governmental consumption Cobb-Douglas utility function.

Bilateral trade of Russian regions with the rest of the world (ROW) is modelled following the Armington approach of product heterogeneity, that is domestic and foreign goods are distinguished by the origin (Armington 1969). We do explicitly account for the existence of trade margins on exports. The model includes the trade balance constraint, according to which the value of the country's exports plus the governmental transfers to the rest of the world are equal to the value of the country's imports. All federal districts are linked by bidirectional trade flows of all commodities. Similar to the international trade part, we assume Armingtontype product differentiation between the goods and services produced in different federal districts.

The SUST-RUS model differentiates energy-related emissions of five primary pollutants $\left(\mathrm{CO}_{2}, \mathrm{SO}_{2}, \mathrm{NOx}, \mathrm{PM} 10, \mathrm{NmVOC}\right)$ by federal district, sector and fuel type. Emissions are linked in fixed proportions to fossil fuels burned in final or intermediate production and consumption. Abatement of emissions takes place by (i) inter-and intra-fuel switching, (ii) end-of-pipe abatement technologies $\left(\mathrm{SO}_{2}\right.$ and $\left.\mathrm{NO}_{\mathrm{x}}\right)$ or (iii) energy savings due to production decline.

The model is dynamic, recursive over time, involving dynamics of physical capital accumulation. Recursive dynamics is a structure composed of a sequence of several temporary equilibria. In each time period, the model is solved for an equilibrium given the exogenous conditions assumed for that particular period. The equilibria are connected to each other through physical and human capital accumulation as well as through changes in migration flows and the number of operating firms. Thus, the endogenous determination of investment behaviour of households and firms is essential for the dynamic part of the model. 


\section{Data and empirical model parameterization}

The SUST-RUS model is based on the most recent accounts of region- and sector-specific production, consumption, bilateral (interregional and international) trade and energy flows in Russia for the year 2006. The main data sources for the construction of the social accounting matrices are publications and publicly available databases of Rosstat, a federal executive body discharging the functions of publishing official statistical information. Though there are a number of input-output tables at our disposal, all of them are not sufficiently detailed to serve as a basis of the SUST-RUS database. The SUST-RUS dataset has been therefore created from the multiple sources by means of input-output estimation techniques, entropy minimization technique and the RAS method $^{3}$ (for a detailed description see Tourdyeva and Heyndrickx, 2011). The choice of the model's base year is closely linked to the choice of the industrial structure. Table 1A (Appendix) summarises regional, sectoral and factor aggregation of the model.

The first step in data processing has amended sectoral resolution of the latest Russian inputoutput table for the year 2006 (IO 2006) which covers 15 industries only, thereby corresponding to the digit-one level in the NACE classification ${ }^{4}$ (Rosstat, 2009). For example, all manufacturing industries in this data source are aggregated into single code " $\mathrm{D}$ ". To overcome an obvious trade-off between data constraints and a desire to be as detailed as possible in terms of the industrial structure, we used two additional data sources: The inputoutput table for the year 1995 (IO 1995) consisting of 110 industries $^{5}$ and input-output table for 2003 (IO 2003) covering 22 sectors (Rosstat, 2006), both based on the old Soviet industrial classification system called OKONH. An entropy minimization technique, similar to Robinson et al. (2001), was used to disaggregate IO 2006 towards 32 industrial sectors in the NACE classification. Figure 1A-3A (Appendix) display major steps of the procedure.

The second step in data processing has improved the regional resolution of a balanced national SAM for the year 2006, using regional production and national account data, provided by Rosstat (2007a). As to the regional structure, the SUST-RUS database encompasses 7 regional social accounting matrices (RSAMs) to capture the economy of

\footnotetext{
${ }^{3}$ The technique applies row and column balancing factors iteratively until the adjusted matrix (the transactions table) satisfies the row and column totals (commodity and industry output). The technique converges to a solution resulting in a balanced I-O matrix

${ }^{4}$ The new Russian industrial classification OKVED, based on "Statistical Classification of Economic Activities in the European Community" (NACE Rev. 2), was adopted in 2004.

${ }^{5}$ The detailed Russian input-output table, consisting of 110 industries for 1995 was not published by Rosstat, it was obtained by CEFIR researchers with not for publication of original data disclamer, though these tables are described in Goskomstat (1998).
} 
Russia's federal districts. All of them are interconnected by trade and income flows, while all RSAMs sum up to the country social accounting matrix.

Data on international trade of the Russian regions in 2006 was obtained from Ruslana Bureau van Dijk database (Bureau van Dijk, 2012).

Our database features rudimentarily initial tax levels which were complemented by the Rosstat publication (Rosstat, 2007b) to estimate the level of social taxes.

For the social module of the SUST-RUS data we use the micro-level household data from the Russia Longitudinal Monitoring Survey for $2006^{6}$. Rosstat provides data on population and population growth rates by federal districts based on the population censuses. Russian Longitudinal Monitoring Survey for 2006 contains detailed information on household composition and labour market history of adult household members, as well as on household income and expenditures. Started in 1994, RLMS is a nationally representative panel survey covering approximately 4,000 households. We define skills of labour force on the base of one-digit International Standard Classification of Occupations (ISCO) (Appendix, Table 2A and Table 3A). The distribution of skill levels across sectors is derived from the international labour organization (ILO) (ILO, 2012). Given the data gap, we assume that the distribution of skill levels within a particular sector is homogenous across the federal districts. To reach interregional comparability income data are corrected by regional subsistence level. Share of wage income by skill type, household type and district are calculated on the base of RLMS data. Level of unemployment by skills is calculated combining the data from Rosstat (2007a) and RLMS (2006).

The main data input for the environmental module comes from the Rosstat industry-level questionnaire (known as the 11TER form ${ }^{7}$ ) which provides energy consumption at disaggregated level for the year 2005. Fuel consumption is differentiated by 4 types of fuel (coal, oil, gas and petrochemicals) for each sector. Emissions factors for primary pollutants are from IEA (2007) and IIASA $(2012)^{8}$. The latter data source was also used to estimate abatement cost curves for $\mathrm{SO}_{2}$ and $\mathrm{NO}_{\mathrm{x}}$.

\footnotetext{
${ }^{6}$ The Russia Longitudinal Monitoring Survey (RLMS) is a series of nationally representative surveys designed to monitor the effects of Russian reforms on the health and economic welfare of households and individuals in the Russian Federation. For more infomation visit: http://www.cpc.unc.edu/projects/rlms-hse.

${ }^{7}$ For the detailed list of Rosstat questionnaires visit: http://www.gks.ru/bgd/free/b12_43/Main.htm.

${ }^{8}$ The distribution of emissions of $\mathrm{SO}_{2}, \mathrm{NO}_{\mathrm{x}}, \mathrm{PM} 10$ and VOC by fuel type was made on the basis of coefficients derived from the GAINS Europe model (IIASA, 2012, available at: http://gains.iiasa.ac.at/gains/EUN/index.login?logout=1 ) which provides sector- and technology specific data for
} 
Finally, we performed a review of applied general equilibrium models with respect to the noncalibrated parameters. In particular, we guided the choice of substitution elasticities between energy and non-energy aggregate using the study by Lokhov and Welsch (2008). The Russiaspecific Armington elasticities are based on Alexeev et al. (2004). Table 4A and 5A (Appendix) provide details.

\section{Policy implementationon}

Like many other governments, the Russian stakeholders find themselves under pressure to design a well-targeted strategy for price deregulation on the domestic gas market. How much further Russia will move at the pace set out in its Energy Strategy until 2030 is currently not clear, as social impacts of continues price increases begin to be forcefully felt throughout the society. The government is now seemingly engaged in trading-off the two objectives: On the one hand, it supports Gazprom's strategic drive to raise profits on domestic market in order to overcome the problem of chronic underinvestment in the gas industry. On the other hand, it is apparently not reluctant to the argument that further price increases would incur tremendous adjustment costs on domestic industry. Likewise, private consumers would face higher energy prices, rising unemployment and hence increasing social inequality.

In this paper, we assume that Russian government will annually increase taxes on final and intermediate consumption of natural gas by $10 \%$ from 2012 through to 2020 . The design of our simulation runs deals with the question on how to resolve the pending trade-off described above. We capture the first dimension in the specification of our policy scenarios by varying the type of economic agents subjecting to gas price reform. Historically, industrial and private energy consumers in Russia were treated in a distinctive manner, though this caused distortions in the purchases of energy goods and energy-using durables. Unlike many other advanced economies, Russia tended to favour private energy users by imposing lower tariffs and disadvantage industrial energy consumers. Differentiation of gas prices among dissimilar economic agents was justified by distributional concerns. This motive would call for a oneside reform covering industrial producers only. But the pressing investment needs of the Russian gas giant can make a deviation from the distribution-driven motives certainly not less likely. The future reform may seek to adjust gas prices on the domestic market for both types of economic agents: consumers and industrial producers in order to create substantial amount

the European part of Russia. We rely on data specified for the scenario BL for GAINS MEC; Nov2008, for the year 2005 . 
of revenues. To address the uncertainty inherent the future scope of price increases, we consider the following set of scenarios:

Con: $\quad$ Consumers face annual gas price increase by $10 \%$ from 2012 onwards;

Pro: $\quad$ Firms face annual gas price increase by $10 \%$ from 2012 onwards;

C\&P: $\quad$ Consumers and firms face annual gas price increase by $10 \%$ from 2012 onwards.

We subsequently employ alternative assumptions regarding the use of additional revenues to examine the conditions under which the Russian government can generate substantial investment inflows for Gazprom without sacrificing industrial competitiveness of energyintensive sectors and rising severe distributional concerns. Basically, we will compare the reference case, where Gazprom retains revenues generated through gas prices increases for infrastructure investments, and a set of scenarios in which the additional revenues are recycled to finance lump-sum transfers and labour tax reductions. Here we will distinguish two main variants. In the first variant, we will allow additional revenues to be fully used for lump-sum transfers or for labour tax decreases. In the second variant, additional revenues will be equally split between alternative recycling options such as Gazprom's investment needs, lump-sum transfers and labour tax cuts. Our very last recycling option will include the increase of governmental spending.

Invest: $\quad$ Total revenues are used to invest in Gazprom's infrastructure;

LumSum: Total revenues are returned to the consumers via lump-sum transfers;

LabTax: Total revenues are used to cut labour taxes;

InvLum: Revenues are split equally to finance Gazprom's investment needs and to pay lump-sum transfers;

InvLab: Revenues are equally split to finance labour tax cuts and lump-sum payments;

Mixed: $\quad$ Revenues are split equally to finance Gazprom's investment needs, to pay lump-sum and to cut labour taxes;

GovCon: $\quad$ Total revenues are used to increase governmental spending. 


\section{Results}

The primary interest of our simulation analysis is to highlight the pending trade-offs between macroeconomic, environmental and distributional implications as a function of (i) actors subjecting to gas price increases and (ii) alternative recycling mechanisms. We report our results, unless otherwise specified, as percentage change of an economic indicator compared to a reference situation - the Business-as-Usual $(\mathrm{BaU})$ - where there is no gas price increases. The subsections $a$. to $e$. show how financial, macroeconomic, environmental and distributional measures evolve across 21 scenarios considered in this paper.

\section{a. Collected revenues and future investments available for Gazprom}

The main motive driving the gas price increases in Russia is the generation of additional investment flows for Gazprom's urgent investment needs. According to IEA (2002), \$105118 billion (in 2006 US\$ billions) are needed to be invested in the Russian gas sector in the period between 2011 and 2020. As generated profits from gas sales form the main source for Gazprom's capital investments, low gas prices on the domestic market explain part of the failure to raise them to the required level (Tgygankova, 2008).

Our results indicate that if domestic prices increase by 10\% annually from 2012 through to 2020, Gazprom's additional total capital investment will be around US\$97 billion. Figure 1 provides the calculated volume of additional financial inflows at the regional level until 2020, assuming the most extended price reform on the domestic gas market: That is when both consumers and producers face gas price increases. In the vertical dimension, the figure aims to capture the amount of revenues collected annually. The horizontal dimension distinguishes the revenues by year and region. We report the figures in 2006 US\$ billions to make them comparable with estimates from the previous studies. Our figures illustrate that the envisaged reform generates substantial financial inflows which lies only slightly below the required level by IEA (2002). Hence, an alternative scope of reform - when only one type of economic agent is targeted - is not desirable because of pure revenue-generating motives and certainly because it introduces distortions into the economy. Regions with relatively high gas consumption such as Urals and Central Federal District will contribute most to the revenue generation. In South and Far East the generated revenues are low, given that gas represents a relatively small share in total energy consumption of the region (Table 1).

There is a big uncertainty about the long run marginal cost for Russian natural gas sector which form the estimation basis for Gazprom's future investment needs. The exploration of 
the newly commissioned fields in more remote areas, with difficult access conditions including offshore, such as Yamal and Shtockman will presumably raise upstream development, transmission and distributional costs. But even if there is a risk of underinvestment, we argue that roughly doubling gas price up to 2020 in comparison to the 2007 levels will provide the Russian gas sector with a lions' share of investments needed.

Figure 1: Projections for future investments available for Gazprom through to 2020 (in 2006 US\$ billions)

\section{The most extended reform covering consumers and producers (C\&P), in 2006 US\$ billions}

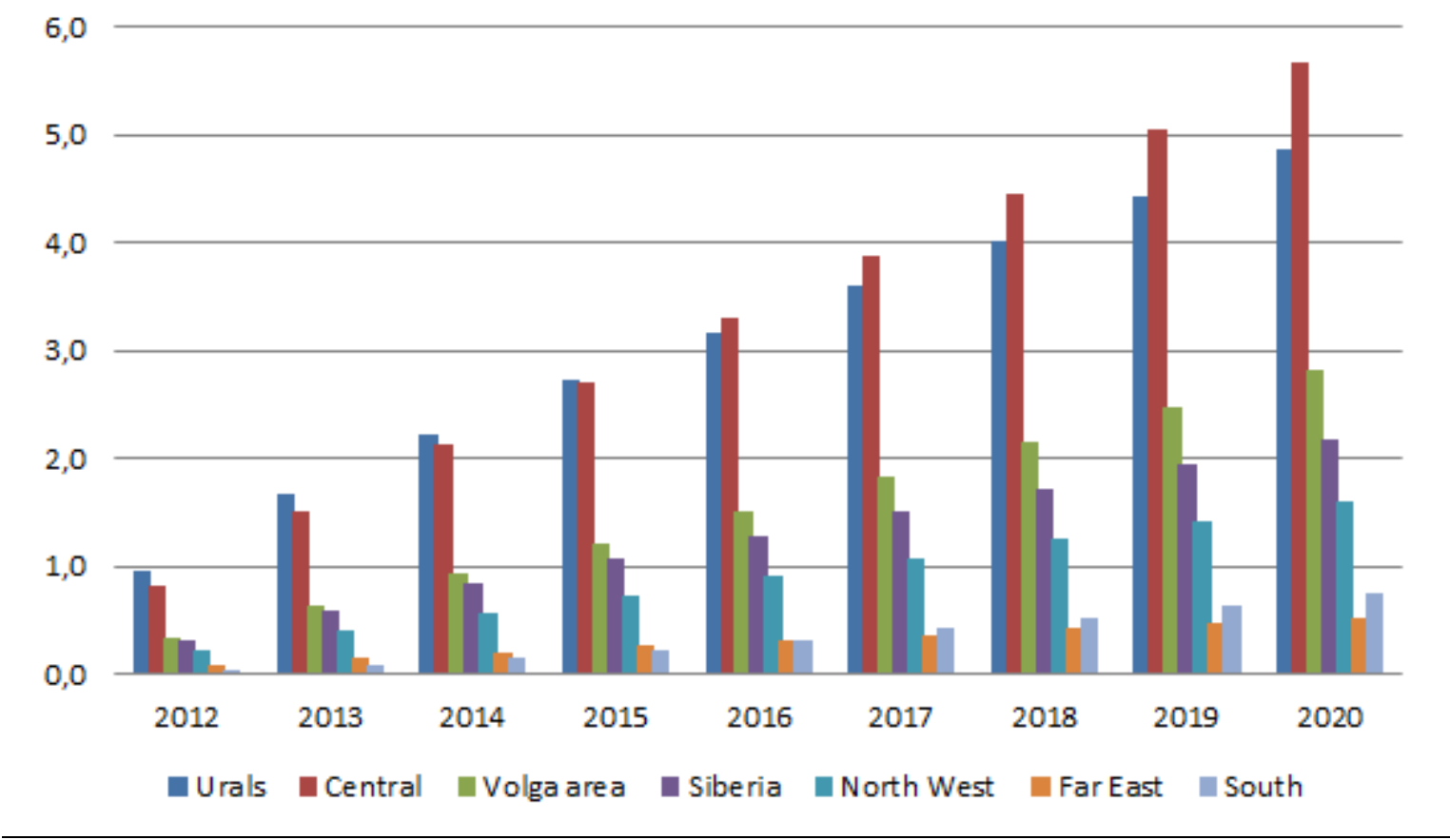

Table 1: Percentage contribution of each fuel type and electricity to total energy requirement in 2007, per region

\begin{tabular}{l||c||c|c|c}
\hline & Gas & Petrol & Coal & Electricity \\
\hline Central & 0,42 & 0,12 & 0,00 & 0,45 \\
\hline North West & 0,41 & 0,07 & 0,00 & 0,52 \\
\hline South & 0,20 & 0,17 & 0,01 & 0,63 \\
\hline Volga area & 0,41 & 0,15 & 0,00 & 0,43 \\
\hline Urals & 0,60 & 0,09 & 0,01 & 0,30 \\
\hline Siberia & 0,40 & 0,12 & 0,00 & 0,48 \\
\hline Far East & 0,39 & 0,05 & 0,00 & 0,56 \\
\hline
\end{tabular}




\section{b. Macroeconomic costs of gas price reform}

There are good reasons for Russian policy makers to be interested in a comprehensive evaluation of gas price reform beyond the impact of price increases on Gazprom's investment capability. Policy interventions typically impose macroeconomic costs to the society rather than create a "win-win" situation. The common metric in general equilibrium analysis to report macroeconomic costs is welfare changes measured by the Hicksian equivalent variation in income.

Figure 2 reveals that welfare losses associated with gas price increases are modest but the redistribution mode has a substantial cost-increasing effect. For any given scope of the reform, the macroeconomic costs are lowest when additional revenues are returned to the consumers via lump-sum. This outcome follows the standard economic principle. The costs are highest when revenues are used to increase the governmental spending. This result is a more country-specific outcome, thereby being in line with some previous findings. Public expenditures in Russia have been repeatedly characterized through a misallocation as they leave substantial room for efficiency gains (see for example the IMF study by Hauner, 2007). Remaining recycling methods are associated with welfare losses on the scale somewhere inbetween. The economic costs are around $1 \%$ in comparison to the $\mathrm{BaU}$ when total revenues are used to invest into Gazprom's infrastructure.

Figure 2: Welfare effects for different reform designs ( $\%$ change from BaU, in 2020)

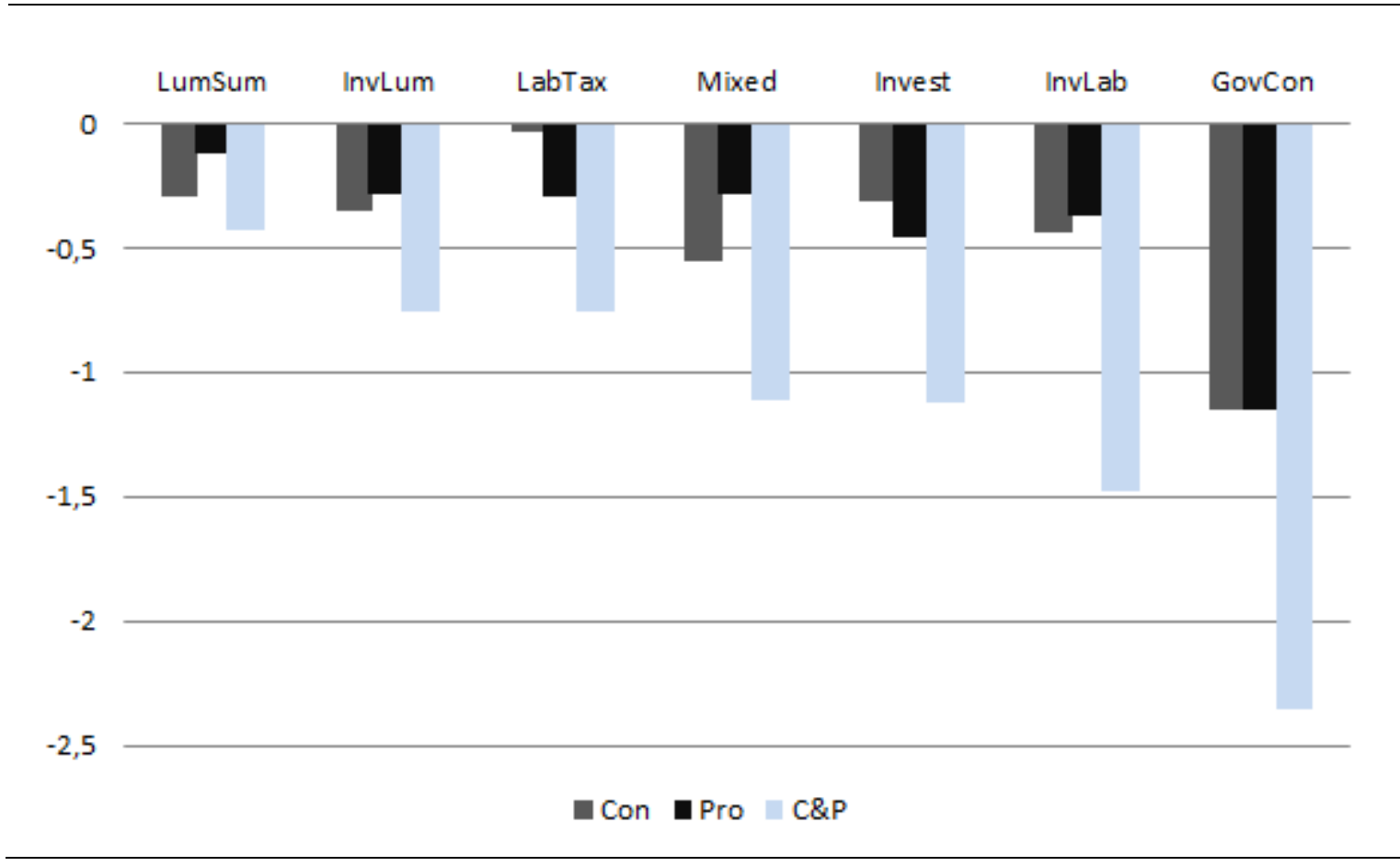




\section{c. Sectoral effects}

A number of previous studies argued that Russian gas users have a significant potential for demand adjustments, primarily in power generation sector and energy-intensive industries (Bashmakov et al., 2008). However, the growing momentum for gas price reform is currently constrained by fears among Russian stakeholders of potentially strong adverse impact that market-based price setting principle in gas sector will have elsewhere in the economy. In this section we address this important question focusing on the sectoral incidence. Figure 3 depicts output effects arising from gas price increases in the year 2020 for selected industries which build a backbone of the Russian economy: the power generation sector and the energyintensive and trade-exposed industries.

This section focuses exclusively on the output index to proxy sectoral implications, because it is the most commonly used measure in a CGE framework (see for other metrics to measure competitiveness impacts: Böhringer and Alexeeva-Talebi, forthcoming). To economize the space, we emphasize the case when both firms and consumers face higher prices increases and consider three alternative recycling mechanisms: (i) using total revenues to invest in Gazprom's infrastructure (Invest), (ii) spending total revenues to increase governmental spending (GovCon) and (iii) splitting revenues equally between Gazprom's investments and cutting labour taxes (InvLab).

Two main conclusions arise from Figure 3. First, sectoral effects are very heterogeneous across the economy. At the lower end of the range, the gas sector will confine the production level by up to some tremendous $25 \%$ in comparison to $\mathrm{BaU}$ in 2020 . Higher gas prices increase the profitability of coal-fired power stations and accelerate the switch away from gas, making coal and coke producing sectors to the biggest winners of the reform. But the impacts are not likely to be very high. Our results are in line with previous studies by Milov et al. (2006), Stern (2005) and Tsygankova (2008) estimating the perspective for coal use in power generation as limited in the upcoming decades. One argument is that a large scale switch towards coal would require enormous investment flows which cannot be mobilized in the short term period. An additional constraint is put by the fact that coal reserves are located in much more remote areas than gas fields making transportation costs even more substantial. 
Figure 3: Output effects for selected industries (\% change from $\mathrm{BaU}$, in 2020)

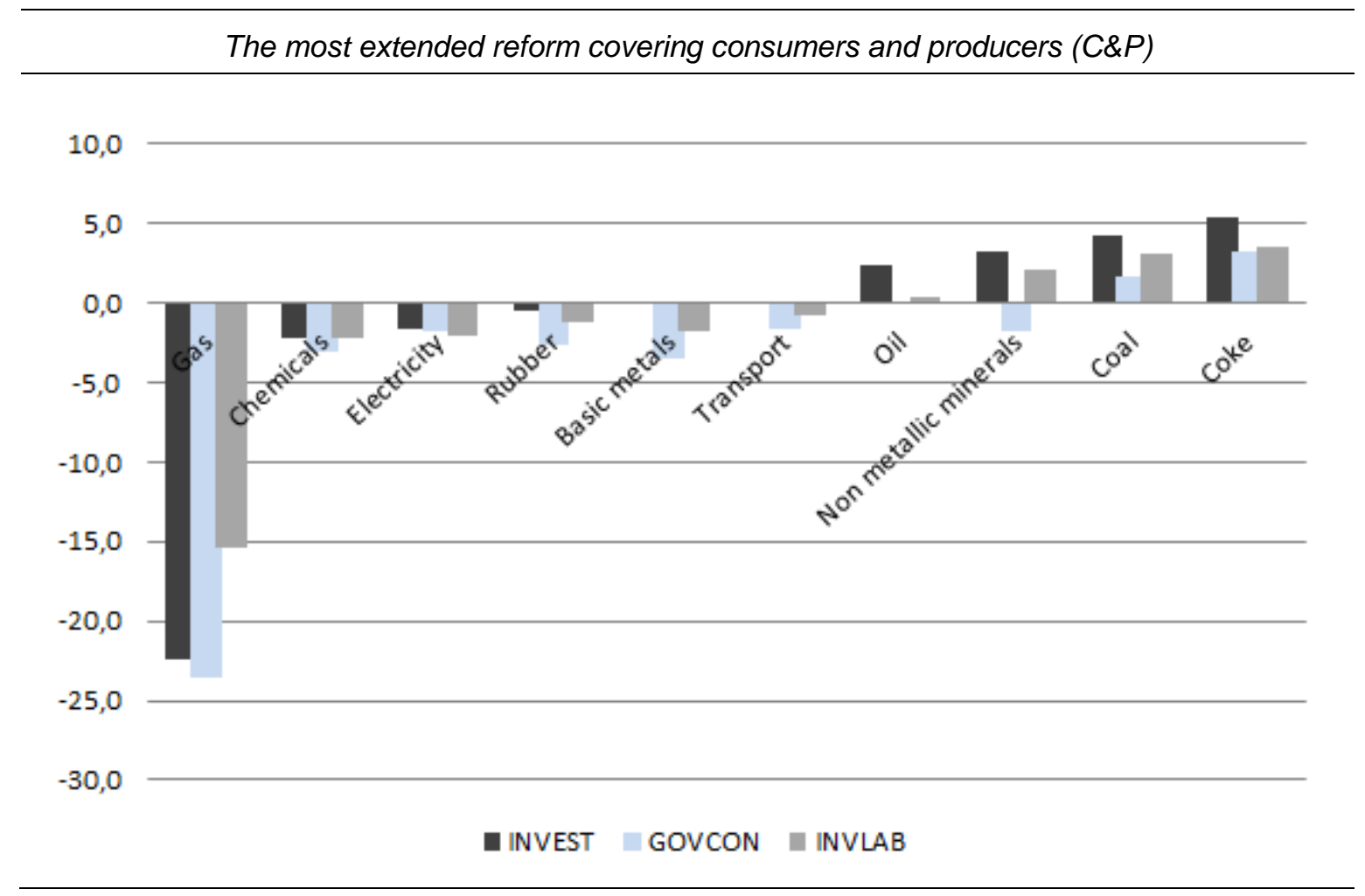

The envisaged reform will affect the Russian heavy industry not only directly via gas price increases but also indirectly through rising electricity prices. From the figure above it seems, however, clear that the energy-intensive and trade-exposed industries will adjust the production level only modestly. This is due to high potential for energy saving in industrial sectors by means other than pure output reduction, in particular by substituting energy with labour and/or capital. To reflect this potential in the SUST-RUS model, we guided the choice of substitution elasticities between energy and non-energy aggregate using the study by Lokhov and Welsch (2008). The employed Russia-specific values are higher than those estimated by Okagawa and Ban (2008) and typically assumed in the global CGE models.

The second insight from Figure 3 is that recycling mechanisms matters for the sectoral implications. In particular, gas price increases accompanied by redistribution of the revenues to finance labour tax cuts and to invest into the Gazprom's infrastructure have more favourable effects over a reform in which the revenues are used to increase the governmental spending. In terms of sectoral incidence, output losses (gains) in all sectors are smallest when revenues are equally split to boost Gazprom's investments and to cut labour taxes (InvLab). 


\section{d. Environmental effects}

Over the last few years, the Russian government started introducing a mix of structural policies to limit the energy consumption and to reduce GHG emissions. The country is still among world's most intensive users of energy, while low energy intensity is endemic in every sector of economy. The heavy industry in particular has inherited an energy-inefficient and carbon-intensive production plants from the Soviet time. Despite some progress, little has been achieved in terms of energy improvement since Russia became independent in the 1990s. The period of economic boom during the 2000s forcefully disclosed the vulnerability of country's "low-energy-efficiency" approach when the shortage of natural gas and electricity supplies to the industry become an factor determining "the limits of growth" (Bashmakov et al., 2008).

In the presence of energy use externalities such as harm to human health or climate change, there is an economic rational to increase gas prices above the long run marginal costs of production. Russia circumnavigated this basic economic principle for decades by providing underpriced gas to the domestic market. Due to the low financial returns, there were no or little incentives for industrial consumers and private households to invest in any energy efficiency measures. Thereby, empirical work in a variety of contexts demonstrated that the fastest improvements in energy productivity were in periods of relatively high energy prices (Allcott and Greenstone, 2012).

In the rhetoric of Russian stakeholders, an upward correction of gas prices is a powerful energy conservation policy that addresses poor energy efficiency concerns through induced factor substitution and technical change. Figure 4 revolves around this argument using the aggregate measure of energy intensity which relates Russia's GDP to its total energy use. Energy efficiency improves as the indicator decreases; the energy efficiency deteriorates as the indicator increases. We argue that the magnitude of changes in energy efficiency depends on (i) the policy implementation, thereby reflecting the on-going debate on what type of economic agents are subject to the gas price reform; (ii) the ease of substitution of energy with labour-capital aggregate in production and non-energy goods in consumption; and (iii) the mode of revenue redistribution (cf. Böhringer and Alexeeva-Talebi, forthcoming).

Two main conclusions arise from Figure 4. First, the policy implementation drives the results most. Substantial improvements in country's overall energy efficiency are feasible only if government charges industrial producers with higher gas prices. Doubling gas prices creates incentives large enough to make use of vast technical energy efficiency potential which exists 
particularly in Russian electricity generation and manufacturing sector (IFC, 2008). On contrary, rising prices for private consumers only will leave the country's energy efficiency virtually unchanged in 2020 in comparison to "doing-nothing case". This outcome is rooted in a rather small fraction of households' gas consumption in total gas consumption in Russia (roughly $11 \%$ ) and a more limited energy saving potential in comparison to the industrial users. Notwithstanding, our results might be slightly underestimated. Some technical studies forecast that substantial energy savings are available in Russia in residential housing, in particular in space and water heating (IFC, 2008). The benefits of energy efficiency measures in residential housing are, however, subject to barriers which might be difficult to overcome in a short-term perspective we are taking in our exercise.

Figure 4: Impact on energy intensity in 2020 (\% vs. BaU) - Varying reform designs

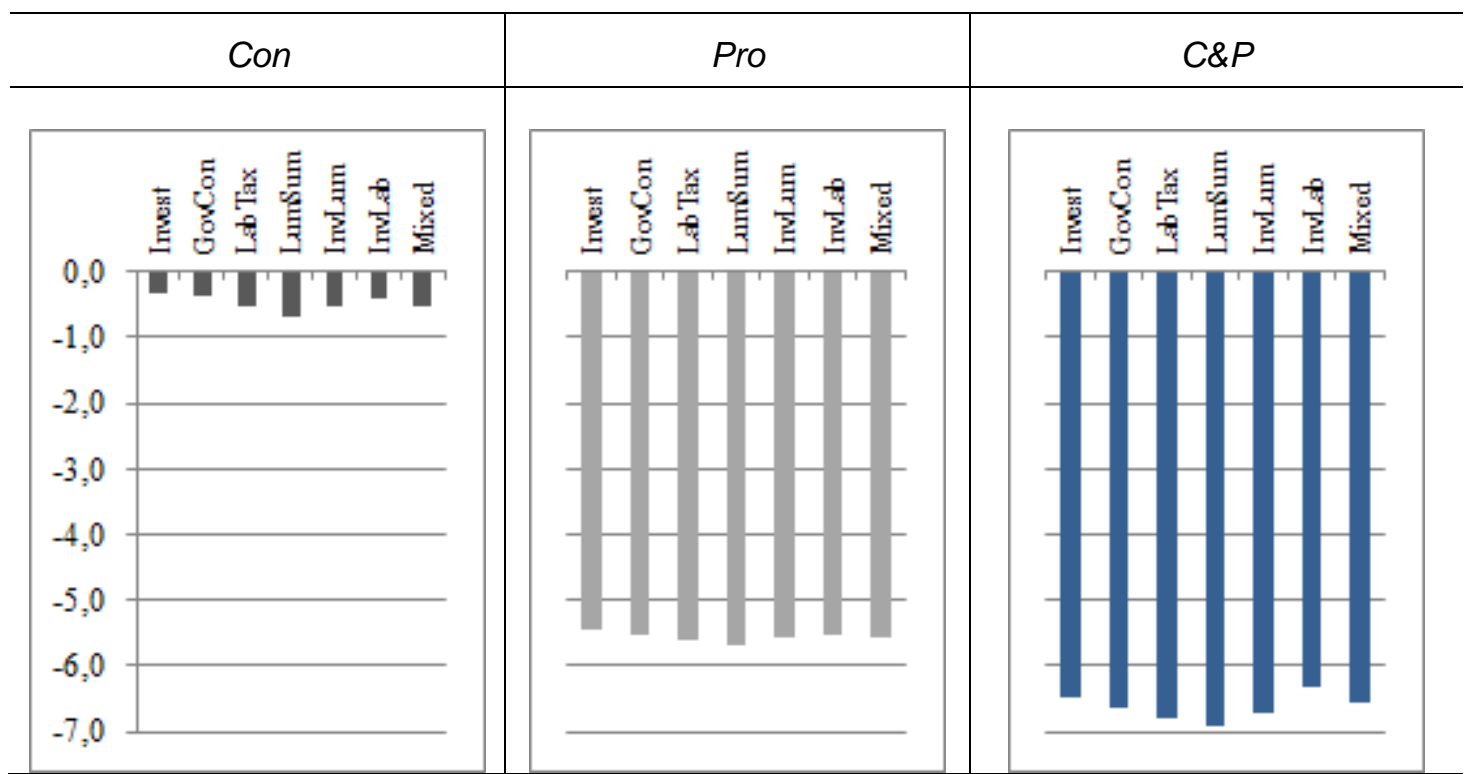

The second result from Figure 4 is that the potential to exploit the revenue-recycling effect (Goulder and Parry, 2008) and, hence, to foster the adoption of energy efficiency measures through a mode of revenue redistribution, is rather limited in Russia. In particular, gas price increases accompanied by redistribution of the revenues to finance labour tax cuts have no additional energy saving benefits over a reform in which the revenues are returned as lumpsum transfers. This is due to a lower level of distortions prevailing on the Russian labour market which makes the substitution towards more labour less attractive as in more industrialized economies.

Figure 5 visualizes how the $\mathrm{CO}_{2}$ intensity reacts to changes in energy efficiency under alternative policy designs. Limiting the policy to the households' side will barely cause any measurable improvements in emissions levels. Under the most extensive scheme covering 
consumers and producers, the large-scale emissions reductions of about $20 \%$ can be achieved compared to the $\mathrm{BaU}$ in 2020. Thus, the gas price liberalisation will bring Russia on a substantially more sustainable path in terms of $\mathrm{CO}_{2}$ emissions but only under the prerequisite that industrial producers will advance in terms of the energetic modernisation. Thereby, there are two effects working in different directions. On the one hand, the reductions in gas demand results in decreasing $\mathrm{CO}_{2}$ emissions. On the other hand, the switch towards more coal let the $\mathrm{CO}_{2}$ emissions increase. Dudek et al. (2006) argued that raising domestic gas prices in Russia is counterproductive from an environmental perspective as it forces a switch towards more coal in existing facilities and boosts emissions. From our calculations it is evident that the first effect dominates resulting in significant net emissions reductions.

Figure 5: Impact on carbon intensity in 2020 (\% vs. BaU) - Varying reform designs

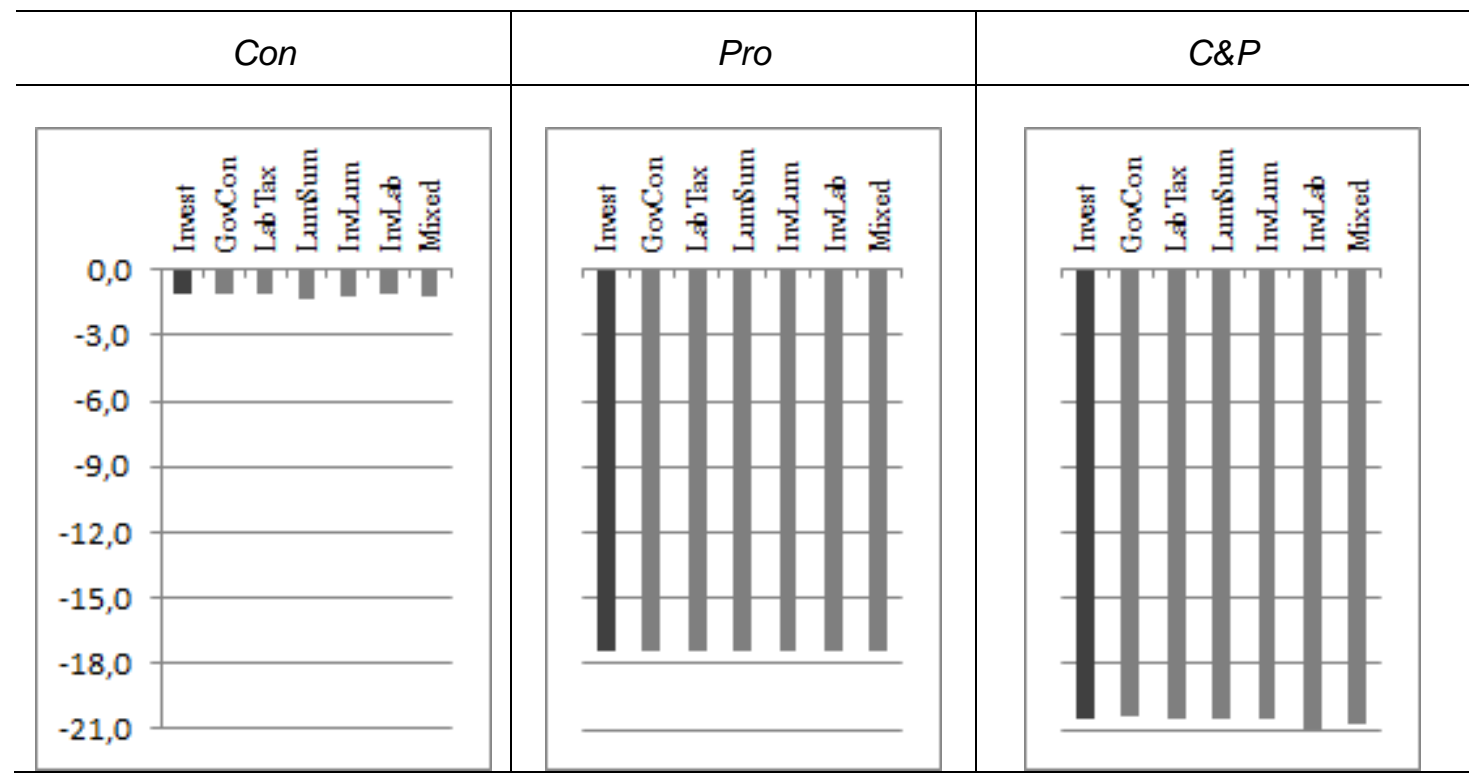

Next, we disaggregate the economy-wide $\mathrm{CO}_{2}$ reduction by region to track the contribution at the federal district level. Table 2 shows some heterogeneity across the Russian regions, with the South reducing most in relative terms vis-à-vis the $\mathrm{BaU}$ levels. From the cost perspective, this outcome is driven by low-cost advantage in abatement options prevailing in the South due to its relatively low gas consumption in comparison to other regional areas (see again Table 1). Impacts at the regional level vary to some extent across redistribution schemes, with InvLab having the strongest effects. 
Table 2: Decreasing regional carbon emissions - taxing consumers and producers: C\&P (\% change from $\mathrm{BaU}, 2020$ )

\begin{tabular}{l||c||c|c|c|c|c|c}
\hline & Invest & GovCon & LabTax & LumSum & InvSum & InvLab & Mixed \\
\hline Central & $\mathbf{- 2 0 , 3}$ & $-20,3$ & $-20,4$ & $-20,5$ & $-20,4$ & $-20,8$ & $-20,6$ \\
\hline North West & $\mathbf{- 2 0 , 0}$ & $-20,2$ & $-20,3$ & $-20,3$ & $-20,2$ & $-20,7$ & $-20,5$ \\
\hline South & $\mathbf{- 2 4 , 4}$ & $-24,3$ & $-24,5$ & $-24,7$ & $-24,6$ & $-25,2$ & $-25,0$ \\
\hline Volga area & $\mathbf{- 2 1 , 0}$ & $-21,2$ & $-21,3$ & $-21,2$ & $-21,1$ & $-21,7$ & $-21,4$ \\
\hline Urals & $\mathbf{- 2 0 , 3}$ & $-20,0$ & $-20,3$ & $-20,7$ & $-20,5$ & $-21,1$ & $-20,9$ \\
\hline Siberia & $\mathbf{- 1 9 , 8}$ & $-19,7$ & $-20,0$ & $-20,1$ & $-20,0$ & $-20,5$ & $-20,3$ \\
\hline Far East & $\mathbf{- 1 9 , 8}$ & $-19,4$ & $-19,7$ & $-20,0$ & $-19,9$ & $-20,8$ & $-20,4$ \\
\hline
\end{tabular}

In terms environmental impacts, Table 3 reveals finally a trade-off between decreasing global gases $\left(\mathrm{CO}_{2}\right)$ and increasing local gases $\left(\mathrm{SO}_{2}\right)$ due to more extensive coal usage. $\mathrm{SO}_{2}$ emissions increase most in the Far East, a region where main Russian coal reserves are located.

Table 3: Increasing regional $\mathrm{SO}_{2}$ emissions - taxing consumers and producers $(\%$ change from $\mathrm{BaU}, 2020)$

\begin{tabular}{l||r||r|r|r|r|r|r}
\hline & Invest & GovCon & LabTax & LumSum & InvSum & InvLab & Mixed \\
\hline Central & $\mathbf{1 , 1}$ & 0,7 & 0,7 & 0,7 & 0,9 & 0,9 & 0,9 \\
\hline North West & $\mathbf{5 , 2}$ & 4,5 & 4,3 & 4,4 & 4,8 & 4,7 & 4,6 \\
\hline South & $\mathbf{0 , 4}$ & 0,1 & $-0,1$ & $-0,2$ & 0,1 & $-0,2$ & $-0,2$ \\
\hline Volga area & $\mathbf{2 , 1}$ & 1,4 & 1,4 & 1,6 & 1,9 & 1,6 & 1,6 \\
\hline Urals & $\mathbf{4 , 0}$ & 4,4 & 3,9 & 3,4 & 3,7 & 3,5 & 3,4 \\
\hline Siberia & $\mathbf{4 , 8}$ & 4,3 & 3,8 & 3,8 & 4,3 & 4,4 & 4,2 \\
\hline Far East & $\mathbf{1 2 , 3}$ & 13,1 & 12,6 & 12,1 & 12,2 & 11,0 & 11,6 \\
\hline
\end{tabular}

\section{e. Social impacts}

In its Energy Strategy until 2030, Russia identifies the issues of energy poverty as one of the priority areas in the modernization of the energy sector. The precariousness of increasing (energy) poverty and raising inequality from gas price hikes constitutes one of the main obstacles to the continuation of the gas price reform and ultimately to the sustainable energy use in Russia. Notwithstanding the need for further price corrections on the domestic gas market, the Russian government is seeking for a well-targeted strategy to prevent severe hardship. The rational of this section is related to the argument above regarding a potentially strong adverse impact of envisaged gas price increases on the well-being of the poor. Given these concerns, we assess the impact of gas price increases on the poverty and the vulnerability of Russia's population using two different metrics: the Hicksian equivalent 
variation to dissect the inequality in consumption (Figure 6a and Figure 6b) and the Gini coefficient to explore the inequality in income (Table 4).

Figure 6a: Welfare effects for different household types - varying the scope of the reform and distribution mechanisms (\% change from BaU, 2020)

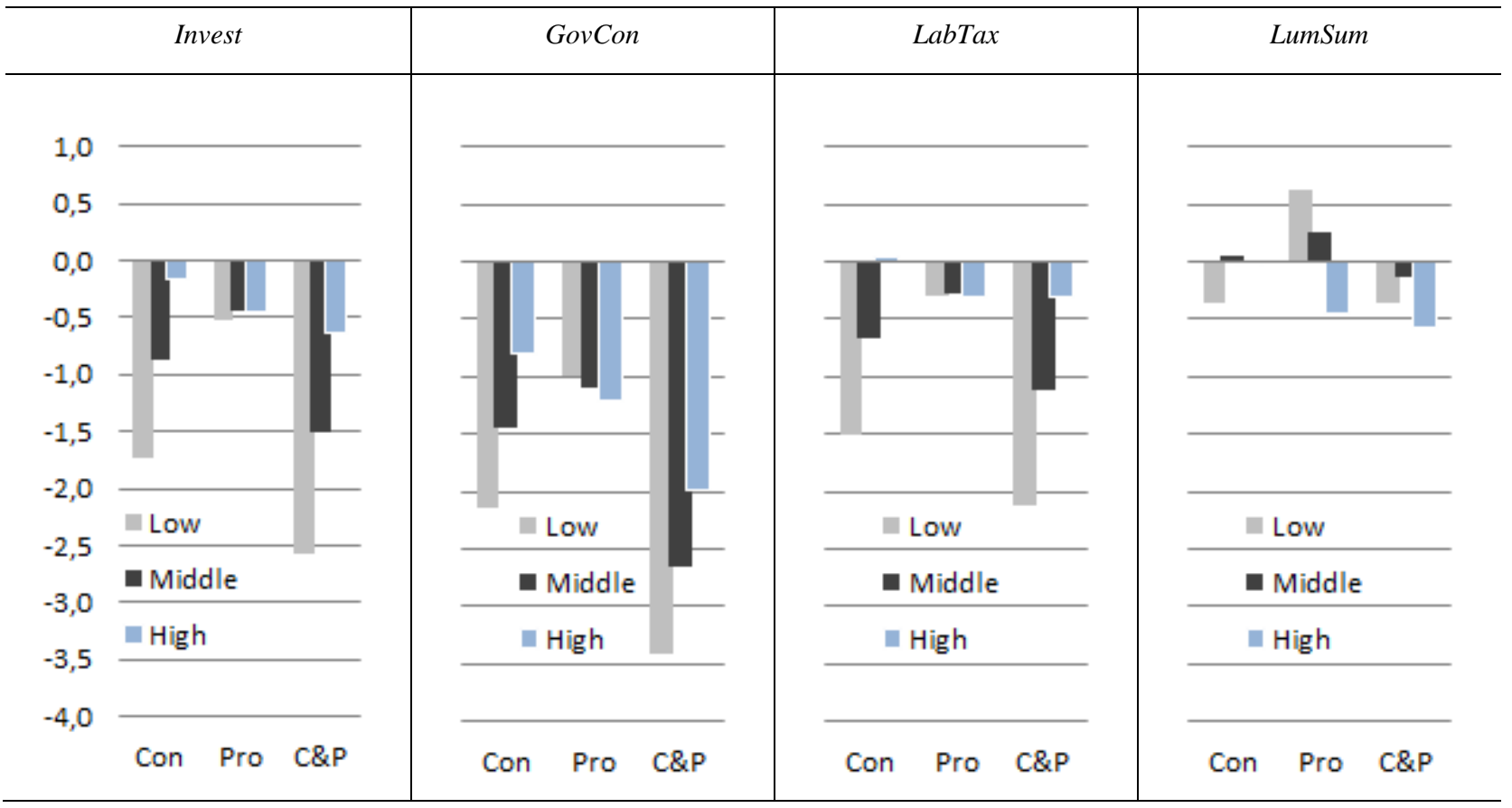

Two main conclusions can be drawn from Figure 6a and Figure 6b. First, doubling gas prices on the domestic market over roughly a decade will have a small though non-negligible adverse impact on the well-being of the Russian society by 2020. This is evidenced by minor adjustments in values of the Hicksian equivalent variation for low, middle and high income households. We therefore argue that envisaged price increases, even within the most farreaching reform proposal where consumers and producers are targeted alike (policy proposal labeled with " $C \& P$ "), will enable the country to emerge from the situation of the extreme poor energy efficiency, without sacrificing the social freedom.

The second conclusion drawn from Figure 6 and Figure $6 \mathrm{~b}$ is that all recycling mechanisms have large redistributive impacts. Deregulating natural gas pricing, notwithstanding, is a regressive policy if prices are gradually increased for consumers only (we label this type of reform with "Con"). This result is primarily rooted in the fact that gas consumption represents a non-negligible, albeit still a rather small, share of direct living costs to the middle class and the poor. In our reference scenario, where Gazprom retains revenues generated through gas prices increases for infrastructure investments, the welfare losses for low income households are among the highest. That is because ultimately the non-poor are the true beneficiaries 
capitalizing on higher returns in the future if Gazprom's investment flows increase today. But recycling revenues to increase the governmental spending makes the poor even worse off. All other recycling measures reduce the adverse impacts on the poor and the middle class, with lump-sum payments making the case as a most suitable mechanism to address the distributional concerns.

Figure 6b: Welfare effects for different household types - varying reforms and distribution mechanisms (\% change from $\mathrm{BaU}, 2020)$

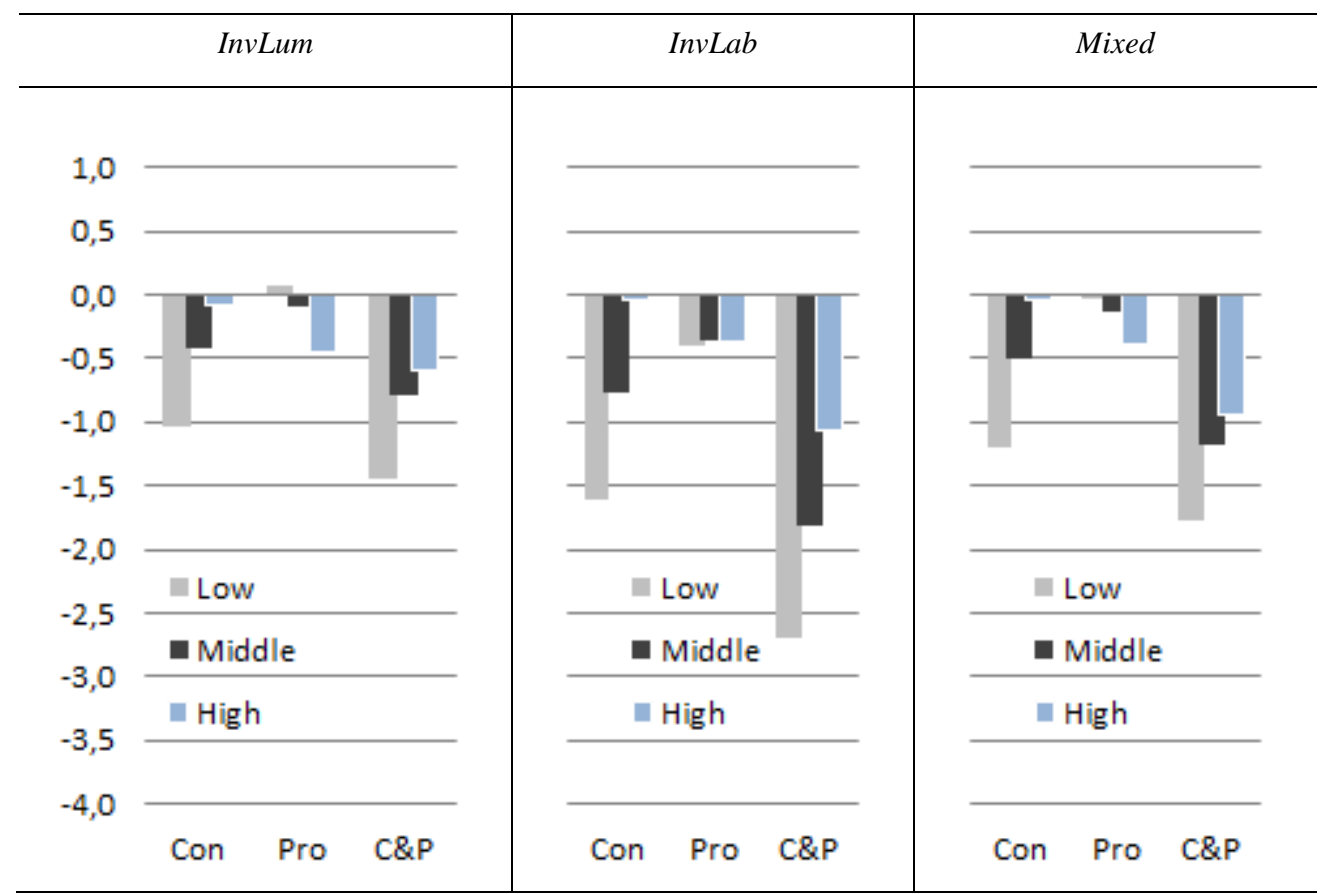

Charging firms in lieu of consumers with higher gas prices (reform proposal labeled with "Pro") might be a superior strategy from a distributional point of view: It will have a moderate and progressive impact on citizen's welfare in comparison to the former option, except for the case that revenues are entirely recycled to finance Gazprom's investment needs. More likely is, however, that reform proposals will seek to adjust gas prices on the domestic market for both types of economic agents: consumers and producers in order to create substantial amount of revenues. In this case, Russian Government is well advised to choose a proper redistribution mechanism to allay the inequality consequences. The ranking of the recycling mechanisms in terms of their adverse impact on the poor, from the least adverse to the most adverse option, is as follows: (i) using revenues for lump-sum payments (LumSum), (ii) splitting revenues equally to finance Gazprom's investment needs and to pay lump-sum transfers (InvLum), (iii) splitting revenues equally to finance Gazprom's investment needs, to pay lump-sum and to cut labour taxes (Mixed), (iv) using total revenues to cut labour taxes (LabTax), (v) using total revenues to invest in Gazprom's infrastructure (Invest), (vi) splitting 
revenues equally between labour tax cuts and Gazprom's investments (InvLab) and finally (vii) spending total revenues to increase governmental spending (GovCon). Hence, the conditions under which the Russian government can generate substantial investment inflows for Gazprom without sacrificing the social freedom is to partially redistribute the revenues via lump-sum payments. Again, the revenues shall not be used to increase the governmental spending as it leaves the consumers in the most unfavourable situation.

Next, we apply one of the widely quoted indicators: the Gini coefficient to measure the impact of gas price reforms on the overall income inequality on a scale from 0 (perfect equality) to 1 (absolute inequality). Some recent estimates establish that Russia's income, despite a conventional wisdom, is more evenly distributed than in any of the other BRIC countries or in the USA. In 2008, the Gini coefficient got the value of roughly 0.42 (Rossiyskaya Gazeta, 2010). The SUST-RUS model projects for the business-as-usual case that Russia will move by 2020 towards slightly more equitable redistribution of wealth, with the Gini coefficient varying by area of residence from some 0.29 (North West) to 0.37 (Far East).

Table 4: Gini coefficient at the regional level - taxing consumers and producers $(\%$ change from $\mathrm{BaU}, 2020$ )

\begin{tabular}{l||r||r|r|r|r|r|r}
\hline & \multicolumn{1}{|c|}{ Invest } & GovCon & \multicolumn{1}{c|}{ LabTax } & LumSum & \multicolumn{1}{c}{ InvSum } & \multicolumn{1}{c}{ InvLab } & \multicolumn{1}{c}{ Mixed } \\
\hline Central & $\mathbf{0 , 3 2}$ & 0,19 & 0,25 & 0,10 & 0,21 & 0,20 & 0,14 \\
\hline North West & $\mathbf{0 , 3 0}$ & 0,21 & 0,22 & 0,11 & 0,20 & 0,19 & 0,14 \\
\hline South & $\mathbf{- 0 , 0 9}$ & $-0,04$ & $-0,04$ & $-0,07$ & $-0,08$ & $-0,05$ & $-0,05$ \\
\hline Volga area & $\mathbf{0 , 2 1}$ & 0,14 & 0,17 & 0,06 & 0,13 & 0,14 & 0,09 \\
\hline Urals & $\mathbf{0 , 2 3}$ & 0,15 & 0,29 & 0,15 & 0,19 & 0,27 & 0,23 \\
\hline Siberia & $\mathbf{0 , 5 3}$ & 0,35 & 0,43 & 0,22 & 0,37 & 0,38 & 0,29 \\
\hline Far East & $\mathbf{0 , 2 3}$ & 0,17 & 0,16 & 0,07 & 0,14 & 0,12 & 0,08 \\
\hline
\end{tabular}

Our results in Table 4 confirm concerns about raising inequality in the case of gas price increases but the reform is not subject to significantly greater disparities within and between the various federal districts of the country. That is even if it targets consumers and producers alike. One of the factors driving inequality up is a rising wage inequality: Firms can create new jobs by substituting energy with labor. The reduced unemployment and thus higher income determined that South appears to be a beneficiary in terms of reduced inequality in comparison with other federal districts. The higher the probability that revenues are returned via lump-sum payments (LumSum) in lieu of the other redistribution mechanisms, the less pronounced becomes the deterioration of the Gini coefficient across the scenarios. According to the Gini index, the least favorable option is to fully utilize tax revenues for Gazprom's 
investment needs as it after all favors the rich most. But again, the increases in inequality within a federal district on a scale of less than $1 \%$ vs. BaU will not create any significant additional burden on the social situation. As the spatial disparities (i.e. disparities between federal districts) increase most under the Invest scenario, a partial redistribution of revenues via lump-sum payments can be used as a remedy to this problem.

Russian policymakers confront the consequences inherent in raising prices on the domestic market for the social dimension. In this section we argued that with an emphasis on inequality issues, the Russian Government may rely on a partial redistribution of revenues towards the middle class and the poor. In essence, the favorable recycling option for a given level of the reforms boils down to a partial redistribution of revenues via lump-sum transfers. The problem with recycling option based on labor tax cuts is that it favors the non-poor as unskilled labor in Russia already benefits from low tax rates.

\section{Conclusions}

From the mid-2000s, the key component of the reforms in the Russian gas sector has become the introduction of a new pricing scheme for natural gas supply at the domestic markets. Historically, low gas prices explained part of the failure to raise Gazprom's investments to the required level and were disincentive for decades to improve country's energy efficiency. Notwithstanding the need for further price corrections, the Russian stakeholders find themselves currently under pressure to design a well-targeted strategy for price deregulation on the domestic gas market. How much further Russia will move at the pace set out in its Energy Strategy until 2030 is not clear at all, as social impacts of continued price increase begin to be forcefully felt throughout society. The growing momentum for gas price reform is increasingly constrained by fears among Russian stakeholders of potentially strong adverse impact that market-based price setting principle in gas sector will have elsewhere in the economy. This paper presents a simple yet flexible framework for evaluating gas price reforms in Russia emphasizing the pending trade-offs between the competing goals.

Five main conclusions can be drawn from our analysis. First, the generation of investment flows in the magnitude required by independent analysts - according to IEA (2002) around \$105-118 billion (in 2006 US\$ billions) between 2011 and 2020 - is feasible only when both households and firms face increasing gas prices. An alternative scope of reform - when only one type of economic agent is targeted - is not desirable because of revenue-generating motives and because it introduces additional distortion into the economy. 
Second, doubling gas prices on the domestic market over roughly a decade will have a small though non-negligible adverse impact on the inequality in the Russian society. We argue that the reform is not subject to any significantly greater disparities within and between the various federal districts of the country.

Third, recycling mechanisms have large distributional impacts. If supportive measures are desired, the favourable option boils down to a partial redistribution of revenues via lump-sum transfers. Russian policymakers are advised to avoid concrete actions that would result in increasing governmental spending instead.

Four, gas price liberalisation will bring Russia on a more sustainable path in terms of energy efficiency. This is, however, only under the prerequisite that industrial producers will advance in terms of energetic modernisation. By contrast, country's energy efficiency will be virtually unchanged if only consumers will face price increases. Notwithstanding, the potential to exploit the revenue-recycling effect and hence to foster the adoption of energy efficiency measures through a mode of revenue redistribution, is rather limited in Russia.

Five, due to a switch to more coal in the production process there is a trade-off between decreasing global greenhouse gases such as $\mathrm{CO}_{2}$ and increasing local acidifying emissions such as $\mathrm{SO}_{2}$. In some regions, the latter might be rather significant.

The results presented in this paper foster counter-argument for those in favour of a reform in natural gas prices. We show that the proposed reform can be realized at low economic cost, without creating greater disparities in terms of increased inequity within and between country's federal districts. Socially adverse effects which may arise from the reform can be avoided or at least mitigated if the revenues are (partially) recycled in favour of poor households. 


\section{Appendix}

a. Model dimensions

In the version of the model used here, Russian Federation is divided in 7 federal districts: Central, North Western, South, Volga Basin, Ural, Siberian and Far Eastern. The sectorial aggregation covers 26 sectors in each federal district.

Table 1A: Model dimensions

\begin{tabular}{|c|c|}
\hline Production sectors & Regions and primary factors \\
\hline Energy & Regions \\
\hline Coal & Central \\
\hline Natural gas & North Western \\
\hline \multirow[t]{4}{*}{ Refined oil products } & South \\
\hline & Volga Basin \\
\hline & Ural \\
\hline & Siberian \\
\hline Non-Energy & Far Eastern \\
\hline \multicolumn{2}{|l|}{ Mining and quarrying } \\
\hline \multicolumn{2}{|l|}{ Food products, beverages and tobacco } \\
\hline Textiles and textile products & Primary factors \\
\hline Leather and leather products & Labour: low, medium, high \\
\hline Wood and wood products & Capital \\
\hline Pulp, paper and paper products & Natural resources: coal, petroleum and gas \\
\hline \multicolumn{2}{|l|}{ Chemicals and chemical products } \\
\hline \multicolumn{2}{|l|}{ Rubber and plastic products } \\
\hline \multicolumn{2}{|l|}{ Non-metallic mineral products } \\
\hline \multicolumn{2}{|l|}{ Basic metals } \\
\hline \multicolumn{2}{|l|}{ Machinery and equipment } \\
\hline \multicolumn{2}{|l|}{ Electrical and optical equipment } \\
\hline \multicolumn{2}{|l|}{ Transport equipment } \\
\hline \multicolumn{2}{|l|}{ Manufacturing n.e.c. } \\
\hline \multicolumn{2}{|l|}{ Electricity distribution } \\
\hline \multicolumn{2}{|l|}{ Electricity generation } \\
\hline \multicolumn{2}{|l|}{ Construction } \\
\hline \multicolumn{2}{|l|}{ Wholesale and retail trade } \\
\hline \multicolumn{2}{|l|}{ Hotels and restaurants } \\
\hline \multicolumn{2}{|l|}{ Transport and communication } \\
\hline \multicolumn{2}{|l|}{ Transport } \\
\hline \multicolumn{2}{|l|}{ Financial intermediation } \\
\hline \multicolumn{2}{|l|}{ Public administration and defence } \\
\hline \multicolumn{2}{|l|}{ Real estate, renting } \\
\hline \multicolumn{2}{|l|}{ Education } \\
\hline Health and social work & \\
\hline
\end{tabular}


b. Sectoral disaggregation of the input-output table for the year 2006 (IO 2006)

Each step of the proposed methodology includes several tasks as displayed in the diagrams below.

Figure 1A: Estimation of the Russian SIOT for 2003 in NACE format

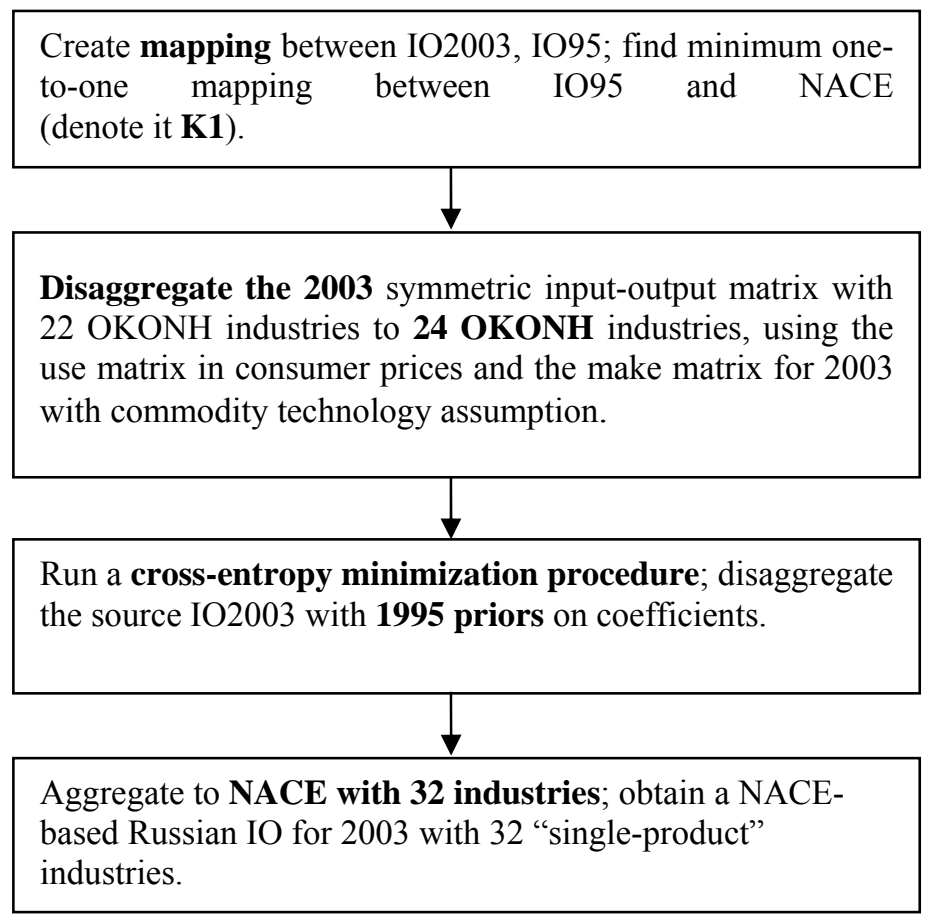

Figure 2A: Estimation of the Russian SIOT for 2006 in disaggregated NACE classification

Estimate 2006 use matrix in producer prices. Assumption: structure of mark-ups is the same as in 2003.

Estimate 2006 symmetric input-output matrix in basic prices
with commodity technology assumption.
Run a cross-entropy minimization procedure; disaggregate
the estimated symmetric input-output matrix for 2006 with
$\mathbf{2 0 0 3}$ priors on coefficients.


Figure 3A: Estimation of the Russian regional symmetric input-output matrices in disaggregated NACE classification

Estimate 2006 use matrix in producer prices.

Assumption: structure of mark-ups is the same as in 2003.

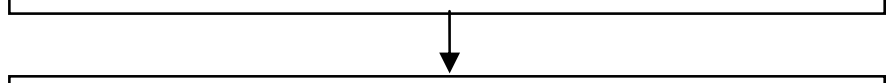

Estimate 2006 symmetric input-output matrix in basic prices with commodity technology assumption.

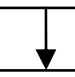

Run a cross-entropy minimization procedure; disaggregate the estimated symmetric input-output matrix for 2006 with $\mathbf{2 0 0 3}$ priors on coefficients. 
c. Data sources for the social block of SUST-RUS.

Table 2A: Skills and ISCO codes

\begin{tabular}{l|l|l}
\hline Level of skills & ISCO codes & Occupations \\
\hline Low & 9 & $\begin{array}{l}\text { Elementary (unskilled) occupations } \\
\text { Technicians and associate professionals, clerks, service } \\
\text { workers and market workers, skilled agricultural and } \\
\text { fishery workers, craft and related trades, plant and } \\
\text { machine operators and assemblers }\end{array}$ \\
High & $3-8$ & $\begin{array}{l}\text { Legislators, senior managers, officials and } \\
\text { professionals }\end{array}$ \\
\hline
\end{tabular}

Table 3A: Share of skill use within sector, source: ILO database (average 2006-2007) ${ }^{9}$

\begin{tabular}{l|r|r|r}
\hline Sectors & LS & MS & HS \\
\hline & & & \\
\hline Total & 0.117 & 0.642 & 0.240 \\
\hline A Agriculture, Hunting and Forestry & 0.184 & 0.750 & 0.066 \\
\hline B Fishing & 0.169 & 0.721 & 0.110 \\
\hline C Mining and Quarrying & 0.076 & 0.751 & 0.173 \\
\hline D Manufacturing & 0.125 & 0.676 & 0.199 \\
\hline E Electricity, Gas and Water Supply & 0.074 & 0.727 & 0.200 \\
\hline F Construction & 0.127 & 0.677 & 0.197 \\
\hline G Wholesale and Retail Trade & 0.089 & 0.767 & 0.144 \\
\hline H Hotels and Restaurants & 0.134 & 0.779 & 0.088 \\
\hline I Transport, Storage and Communications & 0.089 & 0.767 & 0.144 \\
\hline J Financial Intermediation & 0.024 & 0.426 & 0.549 \\
\hline K Real Estate, Renting and Business Activities & 0.120 & 0.458 & 0.421 \\
\hline L Public Administration and Defence & 0.121 & 0.369 & 0.510 \\
\hline M Education & 0.121 & 0.369 & 0.510 \\
\hline N Health and Social Work & 0.089 & 0.626 & 0.285 \\
\hline O Other Community, Social and Personal Service & 0.152 & 0.580 & 0.268 \\
\hline Activities & 0.525 & 0.450 & 0.025 \\
\hline P Households with Employed Persons & 0.250 & 0.000 & 0.750 \\
\hline Q Extraterritorial Organizations and Bodies & 0.228 & 0.676 & 0.095 \\
\hline Unemployed & & &
\end{tabular}

\footnotetext{
${ }_{9}^{9}$ Own calculations based on the ILO database. High skilled $=$ isco1, isco2, medium skilled $=$ isco3, isco4, isco5,
} isco6, isco7, low skilled=isco 8 and isco 9 . The data is based on the share of employees, not corrected for wages. 


\section{d. Empirical parameterization of the model}

Table 4A: Exogenous parameter of input substitution

\begin{tabular}{|c|c|c|c|c|c|c|c|}
\hline Production Technologies & KLEM & $\mathbf{M}$ & KLE & KL & ELEC & COAL & $\begin{array}{l}\text { OIL/ } \\
\text { GAS }\end{array}$ \\
\hline Agriculture & 0.392 & 0 & 0.516 & 0.023 & 0.6 & 0.5 & 0.75 \\
\hline Fishing & 0.392 & 0 & 0.516 & 0.023 & 0.6 & 0.5 & 0.75 \\
\hline Coal & 0.729 & 0 & 0.553 & 0.139 & 0.6 & 0.5 & 0.75 \\
\hline Gas & 0.729 & 0 & 0.553 & 0.139 & 0.6 & 0.5 & 0.75 \\
\hline Oil & 0.729 & 0 & 0.553 & 0.139 & 0.6 & 0.5 & 0.75 \\
\hline Mining (non-energy) & 0.729 & 0 & 0.553 & 0.139 & 0.6 & 0.5 & 0.75 \\
\hline Food, beverage and tobacco & 0.729 & 0 & 0.553 & 0.139 & 0.6 & 0.5 & 0.75 \\
\hline Textiles & 0.329 & 0 & 0.395 & 0.382 & 0.6 & 0.5 & 0.75 \\
\hline Leather & 0.722 & 0 & 0.637 & 0.161 & 0.6 & 0.5 & 0.75 \\
\hline Wood & 0.695 & 0 & 0.456 & 0.087 & 0.6 & 0.5 & 0.75 \\
\hline Pulp and paper & 0.187 & 0 & 0.211 & 0.381 & 0.6 & 0.5 & 0.75 \\
\hline Coke, refineries & 0.848 & 0 & 0.529 & 0.334 & 0.6 & 0.5 & 0.75 \\
\hline Chemicals & 0.848 & 0 & 0.529 & 0.334 & 0.6 & 0.5 & 0.75 \\
\hline Rubber and plastics & 0.306 & 0 & 0.411 & 0.358 & 0.6 & 0.5 & 0.75 \\
\hline Non-metallic products & 0.306 & 0 & 0.411 & 0.358 & 0.6 & 0.5 & 0.75 \\
\hline Basic metals & 1.173 & 0 & 0.644 & 0.22 & 0.6 & 0.5 & 0.75 \\
\hline Machinery & 0.13 & 0 & 0.292 & 0.295 & 0.6 & 0.5 & 0.75 \\
\hline Electric and optics & 0.876 & 0 & 0.524 & 0.163 & 0.6 & 0.5 & 0.75 \\
\hline Transport eq. & 0.548 & 0 & 0.519 & 0.144 & 0.6 & 0.5 & 0.75 \\
\hline Other manufacturing & 0.406 & 0 & 0.529 & 0.046 & 0.6 & 0.5 & 0.75 \\
\hline Electricity, gas and water (distrib.) & 0 & 0 & 0.256 & 0.46 & 0.6 & 0.5 & 0.75 \\
\hline Electricity & 0 & 0 & 0.256 & 0.46 & 0.6 & 0.5 & 0.75 \\
\hline Construction & 1.264 & 0 & 0.529 & 0.065 & 0.6 & 0.5 & 0.75 \\
\hline Wholesale trade & 0.9 & 0 & 0.784 & 0.316 & 0.6 & 0.5 & 0.75 \\
\hline Hotels and restaurants & 0.9 & 0 & 0.784 & 0.316 & 0.6 & 0.5 & 0.75 \\
\hline Communication & 0.654 & 0 & 0.518 & 0.37 & 0.6 & 0.5 & 0.75 \\
\hline Transport & 0.352 & 0 & 0.281 & 0.31 & 0.6 & 0.5 & 0.75 \\
\hline Financial intermediation & 0.492 & 0 & 0.32 & 0.264 & 0.6 & 0.5 & 0.75 \\
\hline Government service and defence & 0.9 & 0 & 0.784 & 0.316 & 0.6 & 0.5 & 0.75 \\
\hline $\begin{array}{l}\text { Real estate, renting and business } \\
\text { activities }\end{array}$ & 0.492 & 0 & 0.32 & 0.264 & 0.6 & 0.5 & 0.75 \\
\hline Education & 0.9 & 0 & 0.784 & 0.316 & 0.6 & 0.5 & 0.75 \\
\hline Health and social work & 0.9 & 0 & 0.784 & 0.316 & 0.6 & 0.5 & 0.75 \\
\hline
\end{tabular}


Table 5A: Proposed Armington elasticticities for SUST-RUS model

\begin{tabular}{l|c}
\hline Production Technologies & Armington elasticites \\
\hline Agriculture & 0.6 \\
\hline Fishing & 0.6 \\
\hline Coal & 0.75 \\
\hline Gas & 0.75 \\
\hline Oil & 0.75 \\
\hline Mining (non-energy) & 0.75 \\
\hline Food, beverage and tobacco & 0.6 \\
\hline Textiles & 0.79 \\
\hline Leather & 0.79 \\
\hline Wood & 0.79 \\
\hline Pulp\&Paper & 0.79 \\
\hline Coke, refineries & 0.83 \\
\hline Chemicals & 0.83 \\
\hline Rubber and plastics & 0.83 \\
\hline Non-metallic products & 0.83 \\
\hline Basic metals & 0.81 \\
\hline Machinery & 0.94 \\
\hline Electric and optics & 0.75 \\
\hline Transport Eq. & 0.75 \\
\hline Other manufacturing & 0.61 \\
\hline Electricity, gas and water (distrib.) & 0.75 \\
\hline Electricity & 0.75 \\
\hline Construction & 0.6 \\
\hline Wholesale trade & 0.6 \\
\hline Hotels and restaurants & 0.6 \\
\hline Communication & 0.6 \\
\hline Transport & 0.6 \\
\hline Financial intermediation & 0.6 \\
\hline Government service and defence & 0.6 \\
\hline Real estate, renting and business activities & 0.6 \\
\hline Education & 0.6 \\
\hline Health and social work & 0.6 \\
\hline & \\
\hline & \\
\hline
\end{tabular}




\section{References}

Allcott, H. and M. Greenstone (2012), Is There an Energy Efficiency Gap?, NBER Working Paper No. 17766, Cambridge.

Alekseev, A., Sokolov, D., Tourdyeva, N. and K. Yudaeva (2004), Estimating the Effects of EU Enlargement: WTO Accession and the Formation of FTA with EU or CIS on the Russian Economy, NES-CEFIR. Document is available at: https://www.gtap.agecon.purdue.edu/resources/download/1887.pdf.

Armington, P.S. (1969), A Theory of Demand for Products Distinguished by Place of Production, IMF Staff Papers 16, IMF, Washington, DC.

Bashmakov, I., Borisov, K., Dzedzichek, M., Gritsevich, I. and A. Lunin (2008), Resource of Energy Efficiency in Russia: Scale, Costs and Benefits, Center for Energy Efficiency, Moscow.

Böhringer, C. and V. Alexeeva-Talebi (forthcoming), Unilateral Climate Policy and Competitiveness: Economic Implications of Differential Emission Pricing, The World Economy.

Bureau van Dijk (2012), Ruslana Database. Data are available at: http://www.bvdinfo.com/Products/Company-Information/National/RUSLANA.aspx

Carlton, Denis and Jeffrey Perloff (2000), Modern Industrial Organization, 3rd edition, Harper Collins.

Dudek, D.J., Golub, A.A. and E.B. Strukova (2006), Should Russia Increase Domestic Prices For Natural Gas?, Energy Policy 34, 1659-1670.

Gazprom (2011), Gazprom in Figures 2006-2010: Factbook. The document is available at: http://www.gazprom.com/f/posts/55/477129/gazprom-reference-figures-20062010-en.pdf.

Goskomstat (1998), Studies in Methods, Part 2, State Statistical Committee of the Russian Federation, Moscow, 1998. (In Russian: Госкомстат России (1998) Методологические положения по статистике, выпуск второй/ Государственный комитет Российской Федерации по статистике, Москва, 1998.) The document is available at: http://www.gks.ru/bgd/free/B99 10/Main.htm 
Goulder, L.H. and I.W.H. Parry (2008), Instrument Choice in Environmental Policy. The paper is available at: http://www.stanford.edu/ goulder/GoulderParry\%20Instrument\%20Choice\%20\%28REEP\%29\%20Paper\%20-\%20Final.pdf.

Fujita, M., Krugman, P. and A. Venables (1999), The Spatial Economy: Cities, Regions, and International Trade, The MIT Press, Cambridge.

Federal Tariff Service (2011), Decree on Tariffs from 9 December 2011, Moscow. The newspaper article is available in Russian at: http://open.lexpro.ru/document/20729691.

Hauner, D. (2007), Benchmarking the Efficiency of Public Expenditure in the Russian Federation, IMF Working Paper, Washington. The study is available at: http://www.imf.org/external/pubs/ft/wp/2007/wp07246.pdf.

Heyndrickx, C., Alexeeva-Talebi, V. and N. Tourdyeva (2011), Spatial-EconomicEcological Model for the Assessment of Sustainability Policies of the Russian Federation: Description of the Economic Model, Mathematical Formulation and Derivations. Report is available at http://sust-rus.org/wp-content/uploads/2010/08/wp3 sust-rus-model.pdf.

IFC (2008), Energy Efficiency in Russia: Untapped Reserves, International Finance Corporation (IFC), Washington D.C. Document is available at: http://www.ifc.org/ifcext/rsefp.nsf/AttachmentsByTitle/FINAL_EE_report_Engl.pdf/\$FILE/F inal_EE_report_engl.pdf.

IEA (2002), Russian Energy Survey 2002, International Energy Agency, Paris.

IEA (2007), $\mathrm{CO}_{2}$ Emissions From Fuel Combustion 2007 edition, International Energy Agency, Paris.

IIASA (2012), The Gains Model, http://gains.iiasa.ac.at/gains/EUN/index.login?logout.

ILO (2012), LABORSTA Internet, Data are available at: http://laborsta.ilo.org/.

Kerkelä, L. (2004), Distortion Costs and Effects of Price Liberalisation in Russian Energy Markets: A CGE Analysis, Discussion Papers No. 2, BOFIT, Helsinki.

Krugman P. (1991), Increasing Returns and Economic Geography, Journal of Political Economy 99, 483-499.

Locatelli, C. (2003), The Viability of Deregulation in the Russian Gas Industry, The Journal of Energy and Development 28(2), 221-238. 
Lokhov, R. and H. Welsch (2008), Emissions Trading Between Russia and the European Union: a CGE Analysis of Potentials and Impacts, Environmental Economics and Policy Studies 9, 1-23.

Milov, V., Coburn, L.L. and I. Danchenko (2006), Russian Energy Policy 1992-2005. Eurasian Geography and Economics 47(3), 285-313.

Nezavisimaja Gazeta (2012), Gas prices for industrial clients will increase by 15\%, 26 April 2012. The newspaper article is available in Russian at: http://www.ng.ru/economics/news/2012/04/26/1335457959.html.

Neary J.P. (1997), R.C. Geary's Contributions to Economic Theory, in: D. Conniffe (ed.), R.C. Geary, 1893-1983: Irish Statistician, Oak Tree Press, Dublin.

Okagawa, A. and K. Ban (2008), Estimation of Substitution Elasticities for CGE Models, mimeo, Osaka University, Osaka.

Paltsev, S. (2011), Russia's Natural Gas Export Potential up to 2050, CEEPR WP 2011-012, MIT Centre for Energy and Environmental Policy Research, Cambridge.

Robinson, S., Cattaneo, A. and M. El-Said (2001), Updating and Estimating a Social Accounting Matrix Using Cross Entropy Methods, Economic Systems Research 13(1), 47-64.

Rosstat (2006), System of Input-Output Tables of the Russian Federation for 2003, Federal State Statistics Service publication, Moscow, 2006. (In Russian: Росстат (2006), Система Таблиц “Затраты-Выпуск” России за 2003 год/ Статистический сборник, Москва, 2006.) The document is available at: http://www.gks.ru/doc_2006/Zatrat06.zip.

Rosstat (2007a), Russian Regions: Social and Economic Indices, 2007, Federal State Statistics Service Publication, Moscow, 2007. (In Russian: Регионы России. Социальноэкономические показатели. 2007: Р32 Стат. сб. / Росстат. - М., 2007. - 991с.) The document is available at: http://www.gks.ru/bgd/regl/B07_14p/Main.htm.

Rosstat (2007b), Labor and Employment in Russia, 2007, Federal State Statistics Service publication, Moscow, 2007. (In Russian: Труд и занятость в России. 2007: Стат.сб./Росстат.) The document is available at: http://www.gks.ru/bgd/regl/B07 36/Main.htm.

Rosstat (2009), National Accounts of the Russian Federation in 2001 - 2008, Federal State Statistics Service publication, Moscow, 2009. (In Russian: Национальные счета России в 2001 - 2008 годах/ Статистический сборник, Москва, 2009.) The document is available at: http://www.gks.ru/bgd/regl/B09 15/Main.htm . 
Rossiyskaya Gazeta (2010), Gini Coefficient Makes Russia Look More Equitable. Article is available at:

http://www.telegraph.co.uk/sponsored/russianow/business/8046055/Gini-coefficient-makes$\underline{\text { Russia-look-more-equitable.html }}$

Sagen, E.L. and M. Tsygankova (2008), Russian Natural Gas Exports-Will Russian Gas Price Reforms Improve the European Security of Supply?, Energy Policy 36, 867-880.

Scherer, F.M. (1980), Industrial Market Structure and Economic Performance, Chicago: Rand McNally.

Stern, J. (2005), The Future of Russian Gas and Gazprom. Oxford University Press.

Svobodnaja Pressa (2012), The Prices for Gas and Electricity Will Be Adjusted, 27 March 2012. The newspaper article is available in Russian at: http://svpressa.ru/economy/article/53922/.

Tarr, D. G. and P.D Thomson (2004), The Merits of Dual Pricing of Russian Natural Gas, The World Economy 27(8), 1173-1194.

Tarr, D.G (2010), Export Restraints on Russian Natural Gas and Raw Timber: What Are the Economic Impacts? The World Bank Development Research Group, Trade and Integration Team, Policy Research Working Paper 5195.

Tourdyeva, N. and C. Heyndrickx (2011), Spatial-Economic-Ecological Model for the Assessment of Sustainability Policies of the Russian Federation: Description of the Constructed Database, Data Quality and Data Collection Methods. Document is available at: http://sust-rus.org/wp-content/uploads/2010/08/deliverable-2.pdf

Tsygankova, M. (2008), Netback Pricing as a Remedy for the Russian Gas Deficit, Discussion Papers No. 554, Statistics Norway.

Tsygankova, M (2010), When is a Break-up of Gazprom Good for Russia?, Energy Economics, 908-917.

Tsygankova, M (2012), An Evaluation of Alternative Scenarios for the Gazprom Monopoly of Russian Gas Exports, Energy Economics, 153-161. 